\title{
Synthesis and Crystal Structure of 2-(Dichloromethyl)-2-(4-nitrophenyl)-1,3-dioxane
}

\author{
Fei Ye, Chang-Ying Sun, and Ying Fu \\ College of Science, Northeast Agricultural University, Harbin, Heilongjiang 150030, China \\ Correspondence should be addressed to Ying Fu; fuying@neau.edu.cn
}

Received 5 July 2013; Revised 7 November 2013; Accepted 7 November 2013

Academic Editor: Tingyue Gu

Copyright ( 2013 Fei Ye et al. This is an open access article distributed under the Creative Commons Attribution License, which permits unrestricted use, distribution, and reproduction in any medium, provided the original work is properly cited.

\begin{abstract}
A new compound, 2-dichloromethyl-2-p-nitrophenyl-1,3-dioxane, was synthesized and characterized. The crystal structure of the title compound $\left(\mathrm{C}_{11} \mathrm{H}_{11} \mathrm{Cl}_{2} \mathrm{NO}_{4}, M_{r}=292.11\right)$ has been determined by single-crystal X-ray diffraction. The crystal is of monoclinic, space group $P 2{ }_{1} / c$ with $a=11.013(2) \AA, b=14.653(3) \AA, c=7.8693(16) \AA, \alpha=90^{\circ}, \beta=97.06(3)^{\circ}, \gamma=90^{\circ}, V=1260.3(4) \AA^{3}$, $Z=4, F(000)=600, D_{c}=1.540 \mathrm{mg} / \mathrm{cm}^{3}$, the final $R_{1}=0.0508$, and $\omega R_{2}=0.1072$ for observed reflections with $I>2 \sigma(I)$. A total of 12162 reflections were collected, of which 2867 were unique $\left(R_{\text {int }}=0.06999\right)$.
\end{abstract}

\section{Introduction}

The 2-dichloromethyl-1,3-dioxacycloalkane compounds have received considerable attention due to safening activities against herbicidal injuries to crop plants [1]. 2-Dichloromethyl-1,3-dioxacycloalkane derivatives, such as MG-191 [2], have been investigated as herbicide safeners which protected crops from the injury by herbicides $[3,4]$. Various substituents of the dioxacycloalkane have showed different activities, which encouraged us to synthesize novel 2dichloromethyl-1,3-dioxane derivatives with enhanced biological activity.

Several synthetic procedures to obtain 1,3-dioxacycloalkanes have been reported [5-8], but most of these methods employ harsh reaction conditions, expensive catalysts, or poor yields. Microwave-assisted syntheses providing fast, clean, and high-yield transformations have been found several times more convenient and efficient methods to obtain organic compounds. In the view of these facts mentioned above, our objective was to find herbicide safeners with better bioactivity [9] and therefore the title compound was designed to prepare 1,3-dioxane derivative containing 4-nitrophenyl substituent at position 2. Synthesis of 2-dichloromethyl-(4nitrophenyl)-1,3-dioxane (4) was planned by microwaveirradiated acetalization followed by insertion of dichlorocarbene using benzyl triethyl ammonium chloride (TEBA) as phase transfer catalyst. In addition to the synthesis, molecular characterization of this novel compound by X-ray crystallography has been outlined.

\section{Materials and Methods}

2.1. Instruments. All chemicals and solvents were of reagent grade and were used as purchased without further purification. The melting point was determined on a Beijing Taike melting point apparatus (X-4) and was uncorrected. The ${ }^{1} \mathrm{H}$ NMR and ${ }^{13} \mathrm{C}$ NMR spectra were run on a Bruker AVANCE $400 \mathrm{MHz}$ spectrometer with $\mathrm{CDCl}_{3}$ as the solvent and TMS as the internal standard. The mass spectrum was recorded on a Waters Xevo TQ mass spectrometer. The infrared (IR) spectra were recorded in $\mathrm{KBr}$ disks on a Bruker ALPHA-T. The X-ray data were collected on a Rigaku RAXIS-RAPID rapid X-ray diffraction measurement using graphite monochromated Mo Ka radiation $(\lambda=0.71073 \AA)$ at $293(2) \mathrm{K}$.

2.2. Synthesis. The title compound was synthesized according to the route shown in Scheme 1, and the yields were not optimized.

A mixture of $p$-nitrobenzaldehyde ( $1,0.1 \mathrm{~mol}), 1,3$-propanediol (2, $0.15 \mathrm{~mol}), \mathrm{CuSO}_{4}(1.5 \mathrm{~g})$, and cyclohexane $(50 \mathrm{~mL})$ was exposed to microwave radiation for 15 min under reflux 


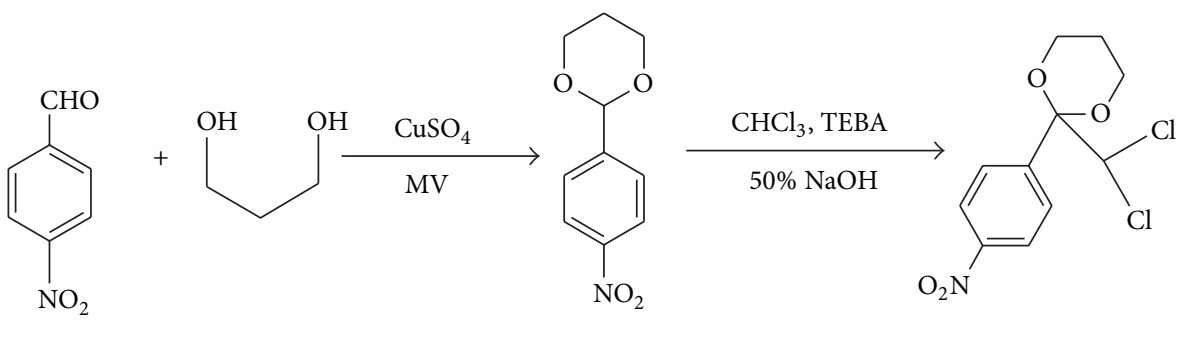

(1)

(2)

(3)

(4)

Scheme 1: Synthesis of the title compound 4.

TABLE 1: Crystal and structure refinement for title compound.

\begin{tabular}{|c|c|}
\hline Item & Value \\
\hline CCDC & 928570 \\
\hline Empirical formula $t$ & $\mathrm{C}_{11} \mathrm{H}_{11} \mathrm{Cl}_{2} \mathrm{NO}_{4}$ \\
\hline Formula weigh & 292.11 \\
\hline Temperature & 293(2) K \\
\hline Radiation $\lambda$ & $0.71073 \AA$ \\
\hline Crystal system, space group & Monoclinic, $P 2_{1} / \mathrm{c}$ \\
\hline Unit cell dimensions & $\begin{array}{c}a=11.013(2) \AA, \alpha=90^{\circ} \\
b=14.653(3) \AA, \beta=97.06(3)^{\circ} \\
c=7.8693(16) \AA, \gamma=90^{\circ}\end{array}$ \\
\hline Volume & $1260.3(4) \AA^{3}$ \\
\hline$Z$ & 4 \\
\hline Calculated density & $1.540 \mathrm{mg} / \mathrm{m}^{3}$ \\
\hline Absorption coefficient & $0.520 \mathrm{~mm}^{-1}$ \\
\hline$F(000)$ & 600 \\
\hline Item & Value \\
\hline Crystal size & $0.27 \times 0.10 \times 0.07 \mathrm{~mm}$ \\
\hline $\begin{array}{l}\text { Theta range for data } \\
\text { collection }\end{array}$ & 3.32 to $27.47 \mathrm{deg}$. \\
\hline Range/indices $(h, k, l)$ & $-14,14 ;-19,19 ;-10,9$ \\
\hline $\begin{array}{l}\text { Reflections } \\
\text { collected/unique }\end{array}$ & $12162 / 2867\left(R_{\mathrm{int}}=0.0699\right)$ \\
\hline $\begin{array}{l}\text { Completeness to theta }= \\
27.47\end{array}$ & $99.1 \%$ \\
\hline $\begin{array}{l}\text { Absorption correction } T_{\min } \\
\text { and } T_{\max }\end{array}$ & 0.9645 and 0.8736 \\
\hline Data/restraints/parameters & $2867 / 0 / 163$ \\
\hline Goodness-of-fit on $F^{2}$ & 1.032 \\
\hline$R_{1}, w \mathrm{R}_{2}[I>2 \sigma(I)]$ & $0.0508,0.1072$ \\
\hline$R_{1}, w \mathrm{R}_{2}$ (all data) & $0.1016,0.1352$ \\
\hline $\begin{array}{l}\text { Largest diff. peak and hole } \\
\left(\mathrm{e} \AA^{-3}\right)\end{array}$ & 0.268 and -0.232 \\
\hline
\end{tabular}

removing the water formed. The reaction mixture was washed with water until the organic phase was colorless. The organic layer was extracted with ethyl acetate and dried over anhydrous $\mathrm{MgSO}_{4}$. The crude product was purified by silica gel chromatography eluting with ethyl acetate-petroleum ether mixture $(10: 1)$. The yield of (3) was $50.9 \%$; m.p. $112-113^{\circ} \mathrm{C}$. IR (KBr): 3105-2856 (C-H), 1600-1519 (Ar, C=C), 1289-1036 (dioxane, C-O); ${ }^{1} \mathrm{H}$ NMR $\left(\mathrm{CDCl}_{3}, 400 \mathrm{MHz}\right) \delta: 7.28-8.25$ (m, 4H, Ar-H), 5.59 (s, 1H, dioxane, C-H), 4.30-4.34, 4.00$4.07\left(\mathrm{~m}, 4 \mathrm{H}\right.$, dioxane, $\left.2 \times \mathrm{O}-\mathrm{CH}_{2}\right), 2.20-2.32,1.56-1.61(\mathrm{~m}$, $2 \mathrm{H}$, dioxane, $\left.\mathrm{CH}_{2}\right) ;{ }^{13} \mathrm{C} \mathrm{NMR}\left(\mathrm{CDCl}_{3}, 100 \mathrm{MHz}\right) \delta: 148.12$, 145.20, 127.18, 127.18, 123.44, 123.44, 99.90, 67.48, 67.48, 25.64. Anal. Calcd for $\mathrm{C}_{10} \mathrm{H}_{11} \mathrm{NO}_{4}$ : C 57.40, $\mathrm{H}$ 5.30, N 6.70. Found: C 57.46, H 5.38, N 6.65.

To a vigorously stirred solution of acetal $(3,0.025 \mathrm{~mol})$ in $\mathrm{CHCl}_{3}(40 \mathrm{~mL})$, anhydrous $\mathrm{Na}_{2} \mathrm{SO}_{4}(30 \mathrm{~g})$, and TEBA $(0.3 \mathrm{~g})$, $50 \%$ aq. $\mathrm{NaOH}(0.25 \mathrm{~mol})$ was added at $0^{\circ} \mathrm{C}$. The solution was stirred continuously for $48 \mathrm{~h}$. Then water $(100 \mathrm{~mL})$ and diethyl ether $(100 \mathrm{~mL})$ were added into the mixture. After layers were separated, the aqueous layer was extracted with ether $(50 \mathrm{~mL})$ for three times. The organic layers were combined and washed with water until $\mathrm{pH} 7$ and dried over anhydrous $\mathrm{MgSO}_{4}$. The ether was removed by distillation and the residue was subjected to silica gel chromatography eluting with ethyl acetate-petroleum ether mixture $(20: 1)$. The yield of (4) was 51.4\%; m.p. 164-165 C. IR (KBr): 3052 (Ar, C-H), 2999-2946 (dioxane, C-H), 2891 (-CHCl ), 1600-1519 (Ar, C=C), 12891208 (dioxane, C-O); ${ }^{1} \mathrm{H}$ NMR $\left(\mathrm{CDCl}_{3}, 400 \mathrm{MHz}\right) \delta: 7.28-$ 8.33 (m, 4H, Ar-H), 5.69 (s, $1 \mathrm{H},-\mathrm{CHCl}_{2}$ ), 3.73-3.79, 4.09$4.13\left(\mathrm{~m}, 4 \mathrm{H}\right.$, dioxane, $\left.2 \times \mathrm{O}-\mathrm{CH}_{2}\right), 2.18-2.28,1.36-1.40(\mathrm{~m}$, $2 \mathrm{H}$, dioxane, $\left.\mathrm{CH}_{2}\right) ;{ }^{13} \mathrm{C} \mathrm{NMR}\left(\mathrm{CDCl}_{3}, 100 \mathrm{MHz}\right) \delta: 148.66$, 140.38, 131.00, 131.00, 123.37, 123.37, 100.17, 75.40, 62.34, 62.34, 24.62. Anal. Calcd for $\mathrm{C}_{11} \mathrm{H}_{11} \mathrm{Cl}_{2} \mathrm{NO}_{4}$ : C 45.36, $\mathrm{H} 3.81, \mathrm{~N} 4.81$. Found: C 45.42, H 3.88, N 4.76. Mass Spectrum: $[\mathrm{M}-1]=290$.

2.3. Crystal Structure Determination. The cube-shaped single crystal of the title compound was grown by slow cooling from a hot saturated solution in ethanol. The crystal with dimensions of $0.27 \times 0.10 \times 0.07 \mathrm{~mm}$ was mounted on a Bruker AXSII CCD area-detector diffractometer with a graphite-monochromated Mo Ka radiation $(\lambda=0.71073 \AA)$ at $293(2) \mathrm{K}$ in the range of $3.32<\theta<27.47^{\circ}$. A total of 12162 reflections were collected, of which 2867 were independent $\left(R_{\mathrm{int}}=0.0699\right)$ and 1676 were observed with $I>2 \sigma(I)$. The structure was solved by direct methods using SHELXS-97 program and the multi-scan absorption corrections were applied to all intensity data. All nonhydrogen atoms were refined isotropically by the full-matrix least square method on $F^{2}$ using SHELXL-97 [10]. The hydrogen atoms were determined with theoretical calculations and refined isotropically. The final fullmatrix least squares refinement gave $R=0.0508 \mathrm{e}^{-1}$ 


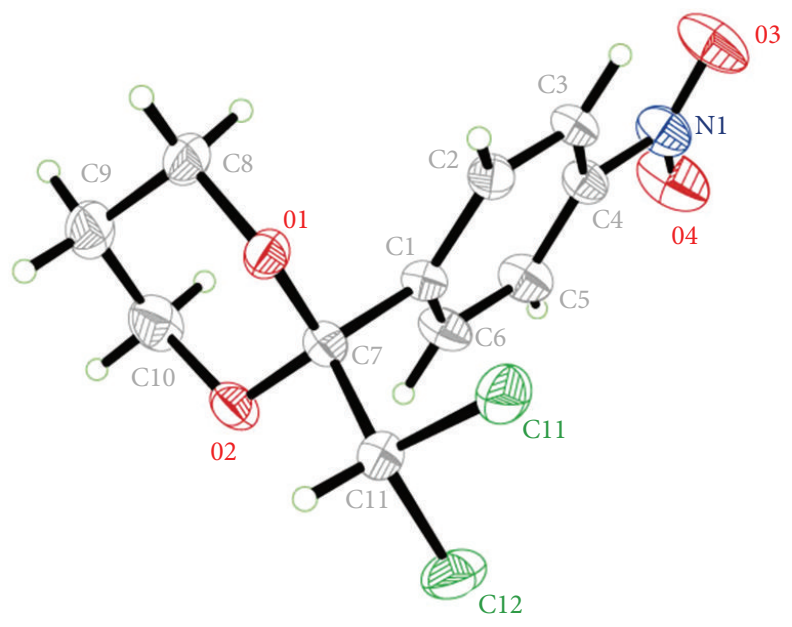

FIGURE 1: Molecular diagram of compound 4 showing 30\% probability ellipsoids.

and $\omega R=0.1072, w=1 /\left[\sigma^{2}\left(F_{o}^{2}\right)+(0.0537 P)^{2}+0.4327 P\right]$ where $P=\left(F_{o}^{2}+2 F_{c}^{2}\right) / 3, S=1.032,\left(\Delta / \sigma_{\max }=0.000\right) \Delta \rho_{\max }=$ $0.268 \mathrm{e} \AA^{-1}$, and $\Delta \rho_{\min }=-0.232 \mathrm{e}^{-1}$. Crystallographic date (excluding structure factors) for the structure in this paper has been deposited with the Cambridge Crystallographic Date Center as supplementary publication number CCDC 928570. Table 1 summarized the crystal data, intensity data collection, and refinement detail for the title compound. The molecular structure and the packing view of the compound were shown in Figures 1 and 2, respectively.

\section{Results and Discussion}

3.1. Synthesis and Structure Identification. The synthesis of the compound $\mathbf{4}$ was carried out in two separate steps. In the first step, a microwave-assisted acetal formation resulted in the 2-(4-nitrophenyl)-1,3-dioxane (3) from which insertion of the dichlorocarbene moiety provided the target molecule 4 (Scheme 1 ) in a poor overall yield $(25 \%)$. The measured data of elemental analytical results is in accord with the theoretical values.

3.2. Crystal Structure. The selected bond lengths and bond angles are shown in Table 2. The atomic coordinates of the nonhydrogen atoms with their equivalent temperature factors were presented in Table 3.

According to $\mathrm{X}$-ray analysis, the structure, the title compound, $\mathrm{C}_{11} \mathrm{H}_{11} \mathrm{Cl}_{2} \mathrm{NO}_{4}$, contained a 1,3-dioxane and a benzene ring. The phenyl ring is almost vertical with the 1,3dioxane ring, with the dihedral angles of $100.4^{\circ}$. The torsion angle of $\mathrm{C}(7)-\mathrm{O}(1)-\mathrm{C}(8)-\mathrm{C}(9)$ was $56.6(3)^{\circ}$. The torsion angle of $\mathrm{C}(7)-\mathrm{O}(2)-\mathrm{C}(10)-\mathrm{C}(9)$ was $-54.0^{\circ}$, which made the 1,3-dioxane similar to chair conformation.

Generally, the average bond lengths and bond angles of ring system (phenyl and 1,3-dioxane) are normal. The bond lengths of $\mathrm{C}-\mathrm{N}$ and $\mathrm{C}-\mathrm{O}$ were close to the typical bond length. In the plane benzene ring, the $\mathrm{C}-\mathrm{C}$ bond lengths range from $1.369(4) \AA$ to $1.396(4) \AA$, almost equal to the values
TABLE 2: Selected bond lengths $(\AA)$ and angles $\left({ }^{\circ}\right)$ for the title compound.

\begin{tabular}{lccc}
\hline & Bond Length $(\AA)$ & & Bond Angle $\left(^{\circ}\right)$ \\
\hline $\mathrm{C}(1)-\mathrm{C}(6)$ & $1.379(4)$ & $\mathrm{C}(6)-\mathrm{C}(1)-\mathrm{C}(2)$ & $120.20(3)$ \\
$\mathrm{C}(1)-\mathrm{C}(2)$ & $1.382(4)$ & $\mathrm{C}(6)-\mathrm{C}(1)-\mathrm{C}(7)$ & $119.80(2)$ \\
$\mathrm{C}(1)-\mathrm{C}(7)$ & $1.543(4)$ & $\mathrm{C}(2)-\mathrm{C}(1)-\mathrm{C}(7)$ & $119.90(3)$ \\
$\mathrm{C}(2)-\mathrm{C}(3)$ & $1.391(4)$ & $\mathrm{C}(1)-\mathrm{C}(2)-\mathrm{C}(3)$ & $120.50(3)$ \\
$\mathrm{C}(3)-\mathrm{C}(4)$ & $1.369(4)$ & $\mathrm{C}(4)-\mathrm{C}(3)-\mathrm{C}(2)$ & $117.90(3)$ \\
$\mathrm{C}(4)-\mathrm{C}(5)$ & $1.372(4)$ & $\mathrm{C}(3)-\mathrm{C}(4)-\mathrm{C}(5)$ & $123.30(3)$ \\
$\mathrm{C}(4)-\mathrm{N}(1)$ & $1.489(4)$ & $\mathrm{C}(3)-\mathrm{C}(4)-\mathrm{N}(1)$ & $118.20(3)$ \\
$\mathrm{C}(5)-\mathrm{C}(6)$ & $1.396(4)$ & $\mathrm{C}(5)-\mathrm{C}(4)-\mathrm{N}(1)$ & $118.50(3)$ \\
$\mathrm{C}(7)-\mathrm{O}(1)$ & $1.409(3)$ & $\mathrm{C}(4)-\mathrm{C}(5)-\mathrm{C}(6)$ & $118.00(3)$ \\
$\mathrm{C}(7)-\mathrm{O}(2)$ & $1.411(3)$ & $\mathrm{C}(1)-\mathrm{C}(6)-\mathrm{C}(5)$ & $120.10(3)$ \\
$\mathrm{C}(7)-\mathrm{C}(11)$ & $1.541(4)$ & $\mathrm{O}(1)-\mathrm{C}(7)-\mathrm{O}(2)$ & $111.50(2)$ \\
$\mathrm{C}(8)-\mathrm{O}(1)$ & $1.454(3)$ & $\mathrm{O}(1)-\mathrm{C}(7)-\mathrm{C}(11)$ & $103.60(2)$ \\
$\mathrm{C}(8)-\mathrm{C}(9)$ & $1.511(5)$ & $\mathrm{O}(2)-\mathrm{C}(7)-\mathrm{C}(11)$ & $103.10(2)$ \\
$\mathrm{C}(9)-\mathrm{C}(10)$ & $1.498(5)$ & $\mathrm{O}(1)-\mathrm{C}(7)-\mathrm{C}(1)$ & $111.90(2)$ \\
$\mathrm{C}(10)-\mathrm{O}(2)$ & $1.450(4)$ & $\mathrm{O}(2)-\mathrm{C}(7)-\mathrm{C}(1)$ & $112.20(2)$ \\
$\mathrm{C}(11)-\mathrm{Cl}(2)$ & $1.764(3)$ & $\mathrm{C}(11)-\mathrm{C}(7)-\mathrm{C}(1)$ & $113.90(2)$ \\
$\mathrm{C}(11)-\mathrm{Cl}(1)$ & $1.772(3)$ & $\mathrm{O}(1)-\mathrm{C}(8)-\mathrm{C}(9)$ & $109.60(3)$ \\
$\mathrm{N}(1)-\mathrm{O}(3)$ & $1.204(4)$ & $\mathrm{C}(10)-\mathrm{C}(9)-\mathrm{C}(8)$ & $109.50(3)$ \\
$\mathrm{N}(1)-\mathrm{O}(4)$ & $1.207(4)$ & $\mathrm{O}(2)-\mathrm{C}(10)-\mathrm{C}(9)$ & $111.10(3)$ \\
& & $\mathrm{C}(7)-\mathrm{C}(11)-\mathrm{Cl}(2)$ & $112.10(2)$ \\
& & $\mathrm{C}(7)-\mathrm{C}(11)-\mathrm{Cl}(1)$ & $111.30(2)$ \\
& & $\mathrm{Cl}(2)-\mathrm{C}(11)-\mathrm{Cl}(1)$ & $109.30(16)$ \\
& & $\mathrm{O}(3)-\mathrm{N}(1)-\mathrm{O}(4)$ & $123.80(3)$ \\
& & $\mathrm{O}(4)-\mathrm{N}(1)-\mathrm{C}(4)$ & $117.90(3)$ \\
& & $\mathrm{C}(7)-\mathrm{O}(1)-\mathrm{C}(8)$ & $113.40(2)$ \\
& & $\mathrm{C}(7)-\mathrm{O}(2)-\mathrm{C}(10)$ & $113.70(2)$ \\
\hline
\end{tabular}

of typical bonds of aromatic structure. And the bond angles of the benzene ring change from $117.9(3)^{\circ}$ to $123.3(3)^{\circ}$, also with the average of $120^{\circ}$. The bond angles of 1,3-dioxane are between 109.50(3) and 113.70(2), close to 109.5, which also confirm the chair conformation of 1,3-dioxane. 


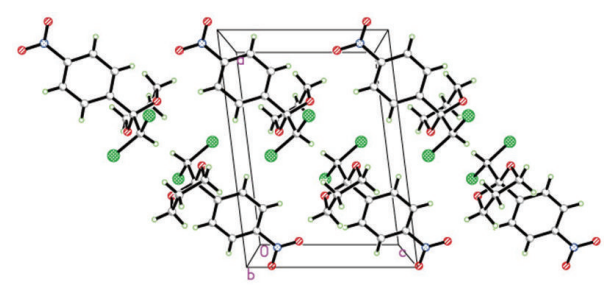

FIgURE 2: The packing view of compound 4.

TABLE 3: Atomic coordinates $\left(\times 10^{4}\right)$ and equivalent isotropic displacement parameter $\left(\times 10^{3}\right)$ nonhydrogen atoms.

\begin{tabular}{lcccc}
\hline & $x$ & $y$ & $z$ & $U_{\text {eq }}$ \\
\hline $\mathrm{C}(1)$ & $7449(3)$ & $5587(2)$ & $2026(3)$ & $39(1)$ \\
$\mathrm{C}(2)$ & $7093(3)$ & $5514(2)$ & $286(4)$ & $43(1)$ \\
$\mathrm{C}(3)$ & $7860(3)$ & $5811(2)$ & $-879(4)$ & $45(1)$ \\
$\mathrm{C}(4)$ & $8963(3)$ & $6185(2)$ & $-242(4)$ & $46(1)$ \\
$\mathrm{C}(5)$ & $9336(3)$ & $6287(3)$ & $1476(4)$ & $56(1)$ \\
$\mathrm{C}(6)$ & $8561(3)$ & $5974(3)$ & $2626(4)$ & $53(1)$ \\
$\mathrm{C}(7)$ & $6584(3)$ & $5263(2)$ & $3305(3)$ & $41(1)$ \\
$\mathrm{C}(8)$ & $6429(3)$ & $3703(2)$ & $2402(4)$ & $52(1)$ \\
$\mathrm{C}(9)$ & $7107(3)$ & $3407(3)$ & $4099(5)$ & $62(1)$ \\
$\mathrm{C}(10)$ & $7912(3)$ & $4169(3)$ & $4840(5)$ & $65(1)$ \\
$\mathrm{C}(11)$ & $5699(3)$ & $6005(2)$ & $3794(4)$ & $44(1)$ \\
$\mathrm{Cl}(1)$ & $4673(1)$ & $6351(1)$ & $1997(1)$ & $56(1)$ \\
$\mathrm{Cl}(2)$ & $6481(1)$ & $6970(1)$ & $4717(1)$ & $69(1)$ \\
$\mathrm{N}(1)$ & $9794(3)$ & $6497(2)$ & $-1481(4)$ & $62(1)$ \\
$\mathrm{O}(1)$ & $5800(2)$ & $4560(1)$ & $2618(2)$ & $43(1)$ \\
$\mathrm{O}(2)$ & $7226(2)$ & $5011(2)$ & $4898(2)$ & $50(1)$ \\
$\mathrm{O}(3)$ & $9484(3)$ & $6373(3)$ & $-2984(3)$ & $93(1)$ \\
$\mathrm{O}(4)$ & $10734(3)$ & $6871(3)$ & $-917(4)$ & $98(1)$ \\
\hline
\end{tabular}

\section{Acknowledgments}

This work was supported by the National Nature Science Foundation of China (no. 31101473), the Natural Science Foundation of Heilongjiang Province (B201212), the Science and Technology Research Project of Heilongjiang Education Department (no. 12521002), and the Research Science Foundation in Technology Innovation of Harbin (2012RFXXN002).

\section{References}

[1] Z. Ekler, F. Dutka, and G. R. Stephenson, "Safener effects on acetochlor toxicity, pptake metabolism and glutathione Stransferase actvitity in maize," Weed Science, vol. 33, no. 4, pp. 311-318, 1993.

[2] I. Jablonkai, "Microsomal oxidation of the herbicides EPTC and acetochlor and of the safener MG-191 in maize," Pesticide Biochemistry and Physiology, vol. 48, no. 2, pp. 98-109, 1994.

[3] I. Jablonkai and F. Dutka, "Uptake, translocation, and metabolism of MG-191 safener in corn (Zea mays L.)," Weed Science, vol. 43, no. 2, pp. 169-174, 1995.
[4] I. Jablonkai, J. Repasi, and F. Dutka, "Effect of the site of MG191 application on acetochlor herbicide uptake, distribution and phytotoxicity," Pesticide Science, vol. 31, no. 1, pp. 91-93, 1991.

[5] M. Curini, F. Epifano, M. C. Marcotullio, and O. Rosati, "An efficient procedure for the preparation of cyclic ketals and thioketals catalyzed by zirconium sulfophenyl phosphonate," Synlett, no. 7, pp. 1182-1184, 2001.

[6] J. S. Yadav, B. V. S. Reddy, R. Srinivas, and T. Ramalingam, "Silica gel-supported metallic sulfates catalyzed chemoselective acetalization of aldehydes under microwave irradiation," Synlett, vol. 2000, no. 5, pp. 701-703, 2000.

[7] M. Moghadam, I. Mohammadpoor-Baltork, S. Tangestaninejad, V. Mirkhani, P. Yazdani, and S. Ghorjipoor, "Highly efficient and chemoselective acetalization of carbonyl compounds catalyzed by new and reusab e zirconyl triflate, $\mathrm{ZrO}(\mathrm{OTF})_{2}$," Heteroatom Chemistry, vol. 20, no. 3, pp. 131-135, 2009.

[8] B. Pério, M.-J. Dozias, P. Jacquault, and J. Hamelin, "Solvent free protection of carbonyl group under microwave irradiation," Tetrahedron Letters, vol. 38, no. 45, pp. 7867-7870, 1997.

[9] F. Ye, Y. Li, Y. Fu, S. Gao, and L. X. Zhao, "Microwave-assisted synthesis and crystal structure of novel 2-dichloromethyl-1, 3dioxolanes," Heterocycles, vol. 86, no. 2, pp. 407-415, 2013.

[10] G. M. Sheldrick, SHELXS97 and SHELXL97, University of Göttingen, Göttingen, Germany, 1997. 

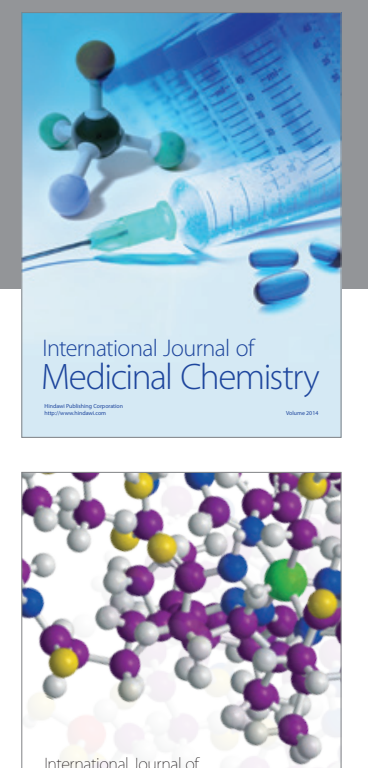

\section{Carbohydrate} Chemistry

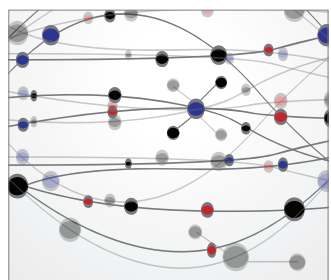

The Scientific World Journal
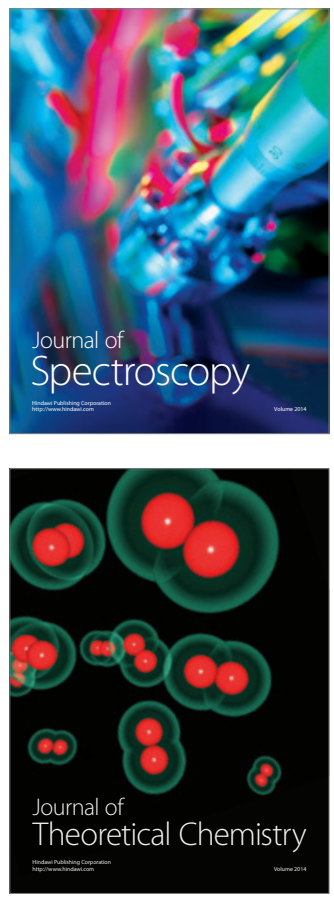
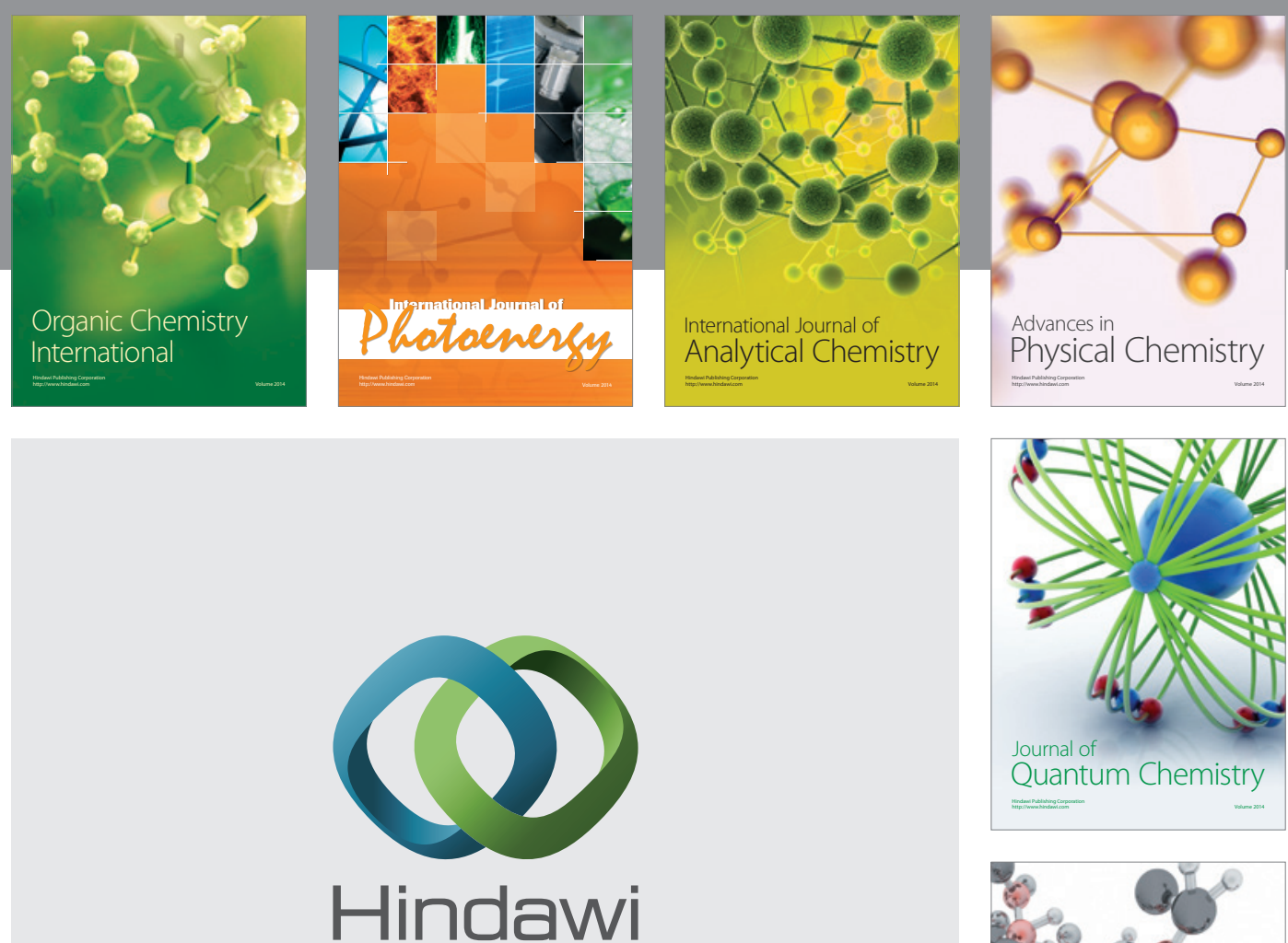

Submit your manuscripts at

http://www.hindawi.com

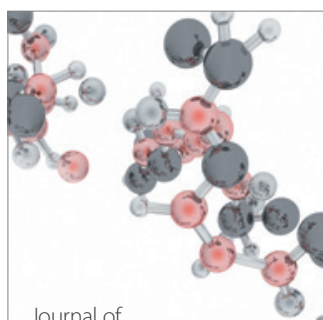

Analytical Methods

in Chemistry

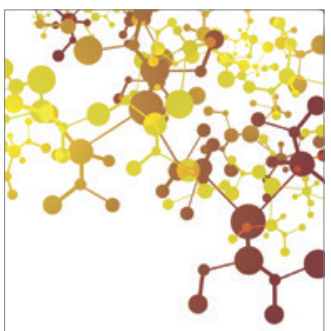

Journal of

Applied Chemistry

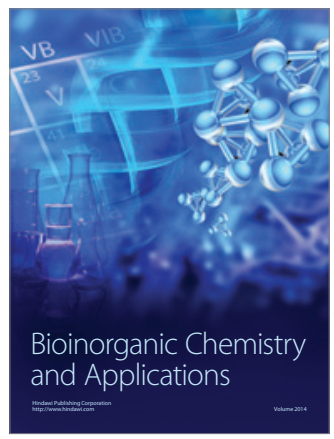

Inorganic Chemistry
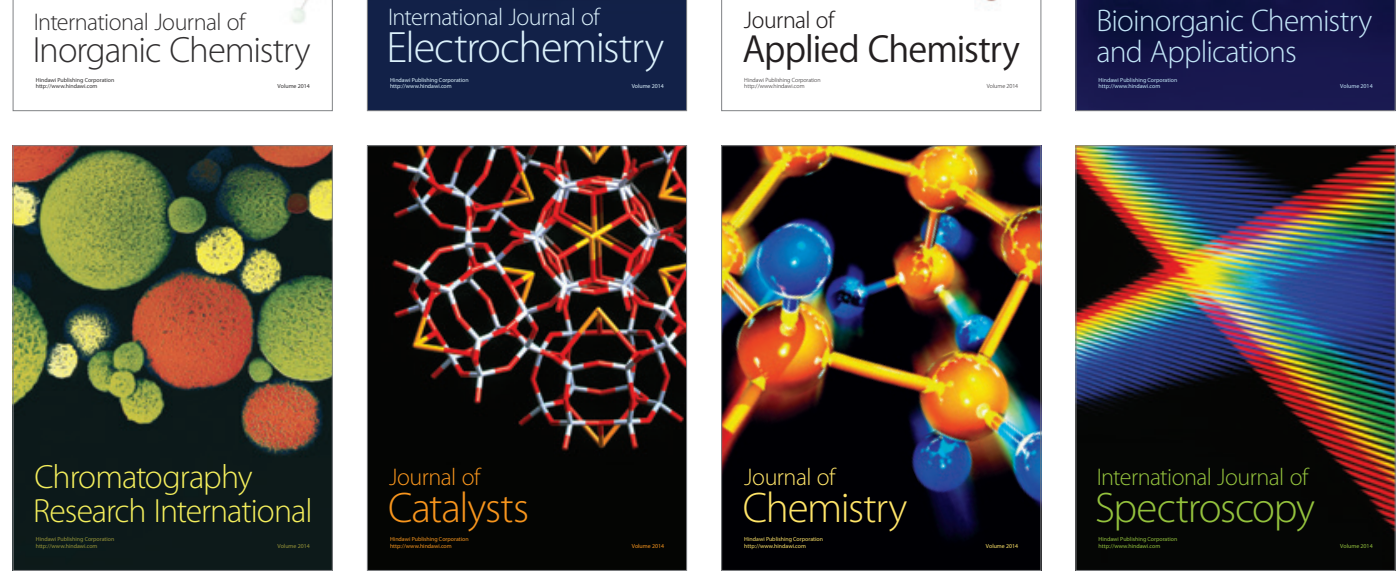